\title{
Acritarch Elektoriskos? williereae (G. \& M. Deflandre, 1965) Vanguestaine, 1979 emend. nov. from the Upper Ordovician of the Siberian Platform: New Morphological and Stratigraphic Data
}

\author{
E. G. Raevskaya ${ }^{a, *}$ and A. V. Dronov ${ }^{b}$ \\ ${ }^{a}$ AO Geologorazvedka, St. Petersburg, 192019 Russia \\ ${ }^{b}$ Geological Institute, Russian Academy of Sciences, Moscow, 119017 Russia \\ *e-mail: lena.raevskaya@mail.ru \\ Received November 27, 2020; revised February 10, 2021; accepted May 22, 2021
}

\begin{abstract}
The morphology of acritarch species Elektoriskos? williereae (G. \& M. Deflandre, 1965) Vanguestaine, 1979, previously considered as a Silurian index of the Llandovery, has been clarified, the diagnosis emended, and the stratigraphic distribution expanded. According to new data, the first appearance of $E$. ? williereae was confined to the upper part of the Baksan Horizon near the boundary of the Sandbian and Katian stages of the Upper Ordovician. Co-occurrence of E.? williereae with representatives of the genera Gordonirundum, Nirundella, Peteinosphaeridium, and Sacculidium is a distinct, well-recognizable palynological characteristic of the Katian deposits of the Siberian Platform which can serve for identification, dating, and correlation of the acritarch-bearing strata. Morphological variations in E.? williereae are a stable diagnostic feature of the species that distinguishes it from other taxa. It is possible that the species was sensitive to paleoenvironments and, probably, highly adaptive, which allowed it, remaining almost unchanged, to overcome the global Late Ordovician cooling, which became fatal for many other groups of organisms.
\end{abstract}

Keywords: acritarchs, Upper Ordovician, Siberian platform, biostratigraphy

DOI: $10.1134 / \mathrm{S} 0869593821060071$

\section{INTRODUCTION}

The stratigraphic significance of acritarchs, especially for the Early Paleozoic and, above all, for the Ordovician, the period of maximum diversity and abundance of these microfossils in all sedimentary basins of the world, is beyond doubt. More than half a century of studying this group has shown that the acritarchs may replace the Ordovician orthostratigraphic groups, such as graptolites, conodonts, and chitinozoans, or supplement them (Raevskaya and Hints, 2019; Raevskaya, 2000, 2007, 2016).

The acritarch group considered as Encertae sedis; it unites various fossils, predominantly of plant nature, similar to photosynthetic eukaryotic plankton (reproductive cysts or mature forms of various fossil unicellular algae) and forming the basis for ancient marine microphytoplankton assemblages (Downie, 1967; Downie et al., 1963). Since the group was created artificially, the acritarch species was defined as a set of unicellular vesicles with certain common morphological features, and the genus was defined as an artificial category that unites species with similar external characteristics (Downie et al., 1963). This classification, based solely on the morphology of microfossils, is undoubtedly subjective. The criteria for identifying species and genus are ambiguous and are interpreted by different authors in different ways. Almost every acritarch morphotype identified at the first stages of the study became a new species especially following the improvement of technical equipment. New taxa were often described using scarce material (to the extent of single specimens) without analyzing variability and taking into account possible paleoecological adaptations. As a result, many of the species attributed to different genera, upon closer study, reveal a common morphological structure, while the species that seem similar at first sight, in fact, belong to different taxa. The imperfection of the acritarch classification, stemming from the nature of this group, is a constant subject of discussion (Fatka and Brocke, 2008; Li et al., 2014; Servais, 1995; Servais et al., 2007, 2008; etc.).

The need for clearer understanding of the structure and variability of key (including Ordovician) taxa and clarification of their stratigraphic ranges and areas of distribution stimulated an increasing number of studies devoted to the revision of the most characteristic genera (Li et al., 2014; Kroeck et al., 2020; NavidiIzad et al., 2020; Playford et al., 1995; Ribecai and Tongiorgi, 1999; Ribecai et al., 2002; Servais et al., 2007, 2008; Wang et al., 2015, 2017; Yan et al., 2010, 2017; etc.). Whereas previously there was a tendency to 
describe as many different acritarch morphotypes as possible as independent species or subspecies, the recent detailed taxonomic revisions involving analysis of obvious trends in morphological variability have led to a reduction in the number of species in the composition of genera (and the number of genera, for that matter).

The taxon Elektoriskos williereae (G. \& M. Deflandre, 1965) Vanguestaine, 1979 (hereinafter, Elektoriskos? williereae) considered in this article has been studied almost as long as the group itself. In the course of these studies, it underwent several revisions and was proposed as one of the markers of the lower boundary of the Silurian, since its first appearance in a number of distant regions of the world (Belgium, England, Canada, United States, etc.) was confined to the lowest part of the Rhuddanian Stage of the Llandovery (Martin, 1989a, 1989b). Now, more than three decades later, interest in this species has reappeared owing to the discovery of numerous specimens of a similar structure in more ancient, Upper Ordovician, sediments of the Siberian Platform (Raevskaya, 2017; Raevskaya and Dronov, 2014, 2015). Moreover, frequent occurrence and pronounced morphology of E.? williereae in the Upper Ordovician of Siberia provides it a key place in the microphytological characteristic of the deposits; the species also may be used as a biostratigraphic marker. This work was aimed at identifying morphological features of the species and clarifying its stratigraphic range.

\section{STRATIGRAPHY}

The Upper Ordovician deposits studied are represented by carbonate and carbonate-terrigenous strata formed in relatively shallow parts of the southwest and northeast of Tungus sedimentary basin, the largest Ordovician basin on the Siberian platform (Fig. 1). The strata are mainly composed of alternating bioclastic thick- or thin-bedded, predominantly gray or greenish gray clayey limestones and mudstones with interlayers of siltstones and sandstones. The stratigraphy of these deposits has been studied in detail (Kanygin et al., 2007, 2017; Tesakov et al., 2003). However, the regional stratigraphic units and their boundaries well recognized and correlated within the Siberian Platform are difficult to compare with the General (Postanovleniya..., 2012) and International (Goldman et al., 2020) Stratigraphic Scales (hereafter GSS and ISS, respectively). The problem lies in the endemic Siberian fauna, evolutionary stages of which defined all the established horizons. The geographical location of the Siberian paleocontinent in equatorial latitudes far from other continents throughout the entire Ordovician (Torsvik and Cocks, 2013), lead to the isolation of the Siberian epicontinental seas and the specific composition not only for benthos (trilobites, brachiopods, gastropods, monoplacophorans, bryozoans) but also for some plankton groups (ostracods, partly conodonts, etc.). The stratigraphic position of several Ordovician horizons of the Siberian Platform relative to the international standard has been indirectly substantiated by the finds of graptolites in the deep-water facies of the surrounding areas (Taimyr, Verkhoyanye, Chukotka, Altai, and Sayany). Bregström et al. (2009) presented the supposed correlation of the Siberian horizons with the subdivisions of the Ordovician of the International Stratigraphic Scale. Further details were given in a review paper on pelagic fauna groups (graptolites, conodonts, chitinozoans) of Siberia (Sennikov et al., 2015).

The lower boundary of the Upper Ordovician GSS and ISS, coinciding with the base of the Sandbian Stage, was assumed on the basis of the first appearance of the graptolite index species $N$. gracilis (Goldman et al., 2020; Postanovleniya..., 2012). On the Siberian platform, it was recognized by comparing faunistic assemblages (brachiopods, ostracods) with those of the Verkhoyansk-Chukotka region, where they are associated with graptolites of the $N$. gracilis zone (Oradovskaya, 1988). The boundary between the Sandbian Stage and the following Katian Stage of the Upper Ordovician of the Siberian Platform does not have reliable criteria for correlation with GSS and ISS and was drawn approximately. The available methods of isotopic dating of the sediments provided so far diminutive but important additional information. The ${ }^{206} \mathrm{~Pb} /{ }^{238} \mathrm{U}$ zircon date obtained for the ash (bentonite) interlayer of the upper part of the Upper Ordovician Mangazei Formation ( $5 \mathrm{~m}$ below its top) exposed in the middle reaches of the Podkamennaya Tunguska River (near the mouth of the right tributary of the Stolbovaya River) allowed the age of the rocks to be established at $450.58 \pm 0.27 \mathrm{Ma}$ (Huff et al., 2014). According to the absolute dating of chronostratigraphic units in the updated ISS version (Goldman et al., 2020), the boundary between the Sandbian and Katian stages is $453 \mathrm{Ma}$, which suggests that the upper part of the Mangazei Formation (at least the upper $5 \mathrm{~m}$ of its stratum) belongs to the Katian Stage. There is no reliable evidence of the presence of the last stage of the Upper Ordovician (Hirnantian) on the Siberian Platform. However, according to some experts (Sennikov et al., 2015), the finds of graptolites Dicellograptus, Orthograptus (s.1.), and Glyptohraptus (s.1.) may support assigning the terminal part of the Ordovician section (Bur Formation) to the bottom of the Hirnantian Stage. The Ordovician-Silurian boundary is marked by a regional nondepositional hiatus of different amplitude (Kanygin et al., 2007, 2017).

\section{MATERIALS AND METHODS}

The rock samples considered in the paper were collected from natural outcrops in the basins of the Bolshaya Nirunda (right tributary of the Podkamennaya Tunguska River, $60 \mathrm{~km}$ downstream of the settlement of Baykit), the Moyero (right tributary of the Kotuy 

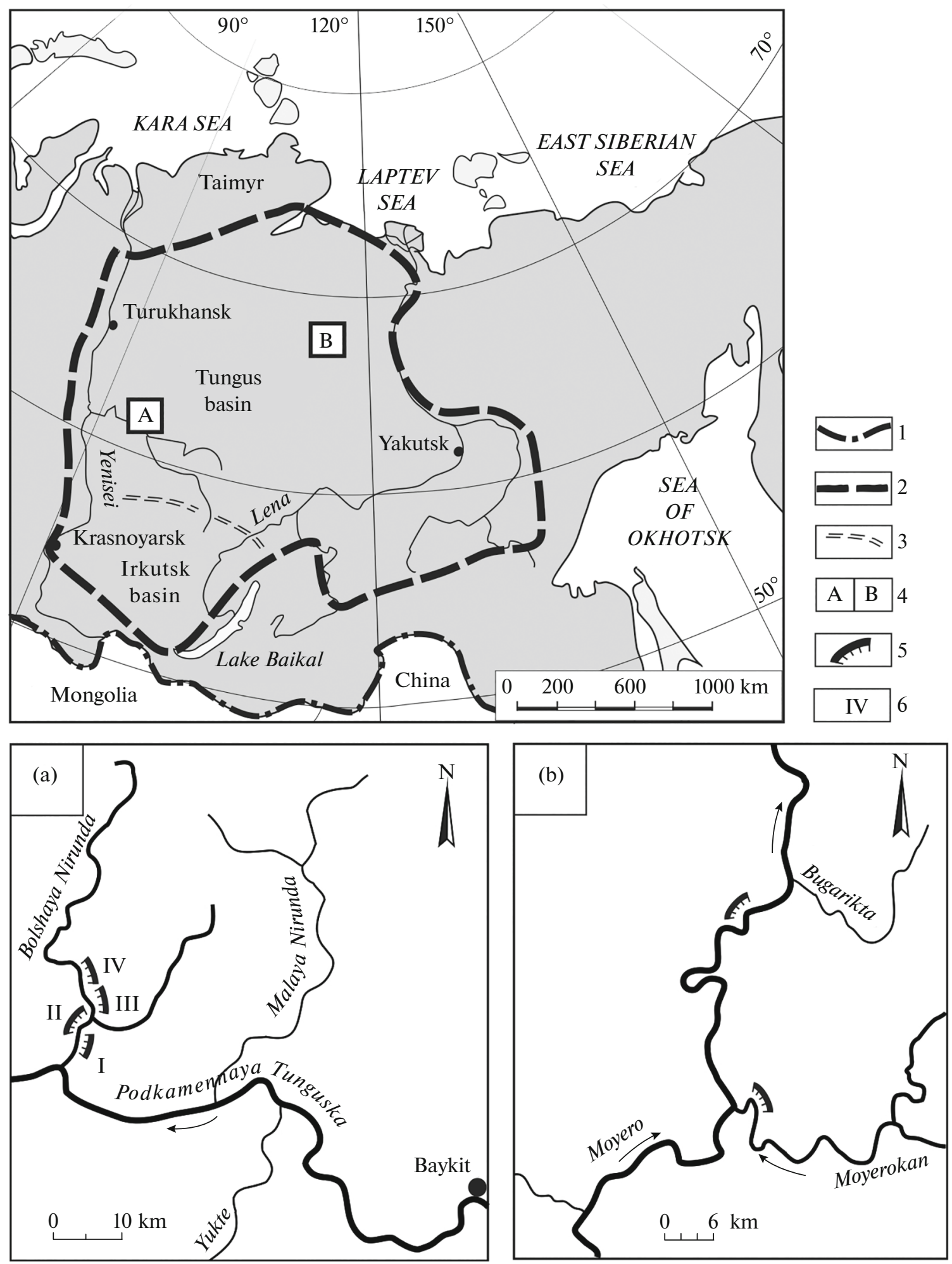

Fig. 1. Map of the studied sections of the Upper Ordovician. (1) Borders of the Russian Federation; (2) boundaries of the Siberian Platform; (3) conditional boundaries of the Tungus and Irkutsk sedimentary basins; (4) location of the sections studied

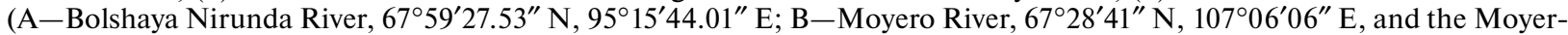
okan River, $67^{\circ} 22^{\prime} 10^{\prime \prime} \mathrm{N}, 104^{\circ} 05^{\prime} 21^{\prime \prime} \mathrm{E}$ ); (5) exposed sections of the Upper Ordovician; (6) outcrop number on the Bolshaya Nirunda River. 
River), and the Moyerokan (right tributary of the Moyero) rivers (Figs. 1a, 1b). A review of the lithological structure, stratigraphy, and modern ideas about the formation of the deposits under consideration was given in (Dronov, 2013, 2017; Kanygin et al., 2007; Pokrovsky et al., 2018). The characteristics of the taxonomic diversity of the accompanying acritarch assemblage across the Bolshaya Nirunda section (Fig. 1a) are given in (Raevskaya and Dronov, 2014; Raevskaya and Servais, 2017; Raevskaya et al., 2016), and that of the Moyero and Moyerokan sections (Fig. 1b) can be found in (Raevskaya and Dronov, 2015; Raevskaya, 2017).

Seventy-eight samples were collected from several Upper Ordovician outcrops along the Bolshaya Nirunda River. The outcrops were composed of a sequence of the Mangazei, Dolbor, Nirunda, and Bur formations corresponding to the Baksan, Dolbor, Nirunda, and Bur horizons, respectively (Kanygin et al., 2007, 2017), with a total thickness of about $100 \mathrm{~m}$. E. ?williereae was found in 35 samples (Fig. 2).

Sixty-five samples were collected from the $60-\mathrm{m}$ section of the Dzheromo Formation, in the basin of the Moyero River and its tributary, the Moyerokan River (Fig. 2). E.? williereae was identified in 26 samples from the interval corresponding to the upper part of the Baksan and Dolbor horizons (Raevskaya and Dronov, 2015; Dronov, 2017).

The maceration of palynological samples was carried out according to the procedure for treating carbonate-terrigenous rocks with hydrochloric and hydrofluoric acids (Raevskaya and Shurekova, 2011) to eliminate the carbonate and silicate components, respectively, followed by washing the insoluble organic residue in distilled water and forcing it through a synthetic sieve with a mesh size of $15 \mu \mathrm{m}$. The isolated palynomorphs had good or satisfactory preservation. The palynological material described in the article is stored in the stratigraphy department of AO Geologorazvedka, St. Petersburg, collection no. SP2009-BN and no. SP2013-MM.

\section{HISTORICAL OVERVIEW}

The considered taxon, originally described from the Lower Silurian deposits of Belgium (Brabant Massif) under the name Baltisphaeridium aff. polytrichum (Valensi, 1947) Stockmans et Williere, 1963, was later found in different intervals of the Silurian in Shropshire (Dorning, 1981; Lister, 1970) and Wales (Hill, 1974; Hill and Dorning, 1984), Great Britain; in Spain (Cramer, 1970; Cramer and Diez, 1968); in Libya and Saudi Arabia (Cramer, 1970; Eisenack et al., 1976); in the province of Ontario, Canada, and the states of New York (Cramer, 1970; Loeblich, 1970; Miller and Eames, 1982), Pennsylvania, and Kentucky (Cramer, 1970), United States; in Quebec, Canada (Martin, 1989a); in Norway (Smelror, 1987); and in Eastern
Siberia (Sheshegova, 1984). Owing to the poorly developed taxonomy of the acritarch, however, the authors attributed it to different genera under different names: Baltisphaeridium aff. polytrichum (Stockmans and Williere, 1963; Martin, 1966), Baltisphaeridium chiggerum (Cramer, 1969), Filisphaeridium williereae (Deflandre and Deflandre-Rigaud, 1965; Lister 1970), Micrhyctridium williereae (Deflandre and Deflandre-Rigaud, 1965; Martin, 1965), Comasphaeridium williereae (Cramer, 1970; Eisenack et al., 1976; Sheshegova, 1984), Elektoriskos pogonius (Eisenack et al., 1976), Elektoriskos williereae (Martin, 1989b; Vanguestaine, 1979), Baltisphaeridium lamellum (Sheshegova, 1984).

The history of authorship, typifying, nomenclature, and synonymy of $E$. williereae recognized by the end of the 20th century is briefly reflected in the fundamental work (Fensome et al., 1990). The Belgian palynologist Martin (1989b) revised the type material from the Llandovery deposits of Belgium using scanning electron microscopy to clarify the morphological structure of the species. On the basis of the study of three hundred specimens, she confirmed the assignment of this species to the genus Elektoriskos Loeblich, 1970 and expanded its diagnosis. According to the author of the revision, the species E. williereae should have "Vesicle globular, with circular outline, clearly distinct from processes. Vesicle wall thin, apparently single-layered, psilate. Processes numerous, usually about one hundred or more, homomorphic, flexuous, filiform, psilate, fragile, of nearly constant diameter from proximal to distal end, apparently solid and without communication with the vesicle cavity. Length of processes at least one and half times the vesicle diameter" (Martin, 1989b, p. 7). Martin did not include the forms from the redeposited complex of acritarchs in the Lower Devonian sequence of the Dinan synclinorium of Belgium described by Vanguestaine (1979) in the synonymics in view of the "conical shape of their processes" and did not confirm the presence of endoand ectoderm in the structure of the E. williereae vesicle mentioned by Cramer (1970). The Siberian species Comasphaeridium williereae and Baltisphaeridium lamellum from the upper Llandovery-Wenlock sections of the Moyero and Kureyka river basins of the Siberian platform described by Sheshegova (1984) were not attributed to E. williereae either, since the low quality images given in her monograph did not allow for an adequate comparison (Martin, 1989b). Regarding the stratigraphic distribution of the species $E$. williereae, according to Martin, it is confined to the Llandoverian deposits. The first appearance of this taxon was recorded slightly above the lower boundary of the Rhuddanian Stage at a level comparable to the base of the Atavograptus atavus (= Orthograptus vesiculosus) graptolite zone, and gradual disappearance was noted at the end of the Telychian Stage within the Monograptus crispus Zone (Martin, 1989b). Thus, E. williereae was presented, in fact, as an index species of the Llandovery. 

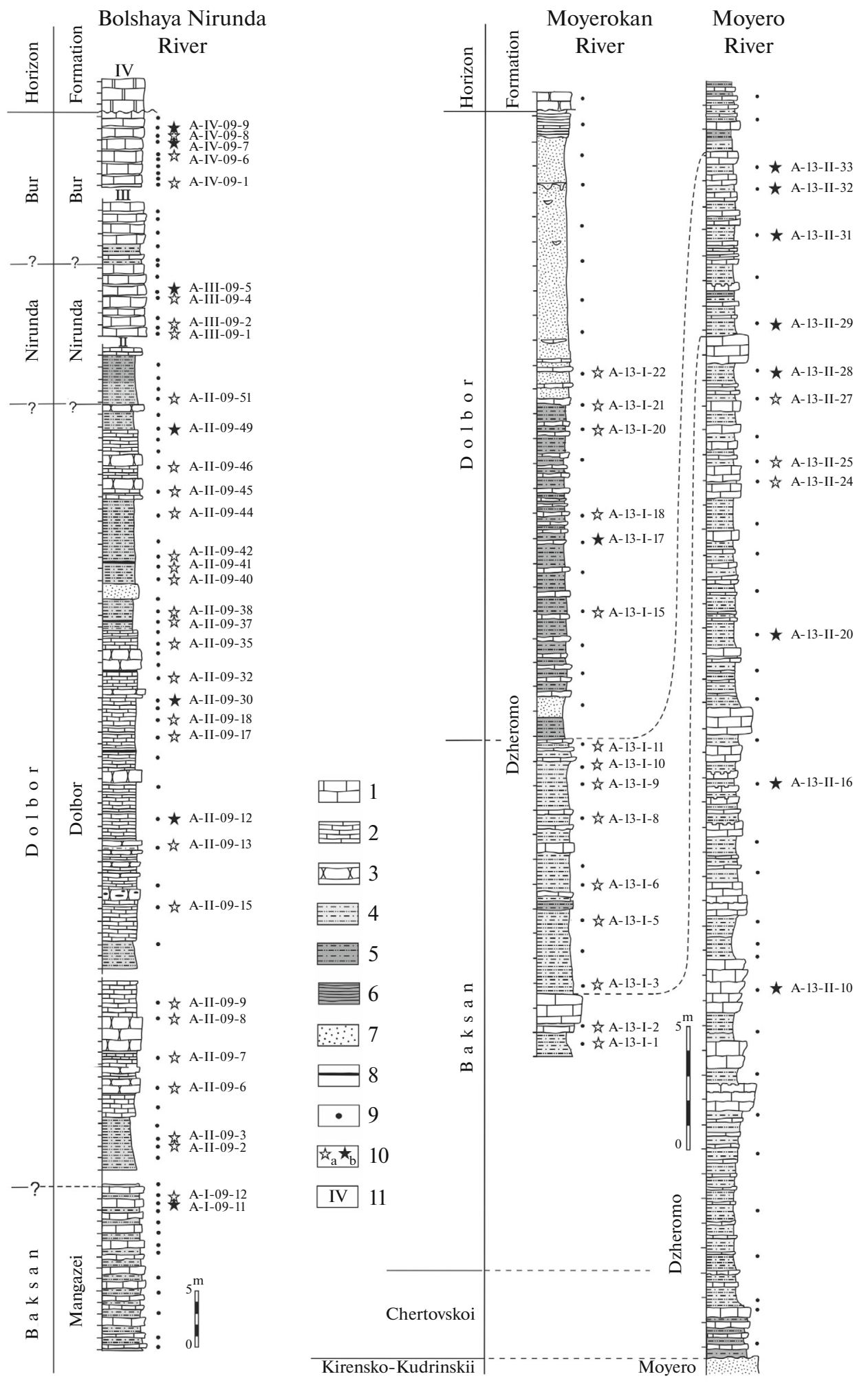

Fig. 2. Upper Ordovician sections in the Bolshaya Nirunda, Moyero, and Moyerokan rivers and the levels of the Elektoriskos? williereae finds. (1) Thin-bedded light gray bioclastic limestone (packstone); (2) thick-bedded dark gray bioclastic limestone (wackestone); (3) dark gray massive limestone (wackestone) with lenses of black flints; (4) greenish gray siltstone; (5) brown siltstone; (6) mudstone; (7) yellowish gray fine-grained quartz sandstone; (8) ash interlayer (bentonite); (9) samples studied; (10) samples containing Elektoriskos? williereae (G. \& M. Deflandre) Vanguestaine, 1974 emend. nov. (a-1 to 10 specimens, $\mathrm{b}-$ more than 10 specimens); (11) number of the outcrop on the Bolshaya Nirunda River. 
The new material obtained from the Upper Ordovician of Siberia required another revision of the morphological and stratigraphic characteristics of this species. The representative palynological collections of recent years include a large number of acritarchs, which are extremely close in structure to $E$. williereae. The revealed morphological features of these vesicles, on one hand, go beyond the diagnoses of this species and genus and, on the other hand, do not constitute a sufficient basis for distinguishing a new taxon or transferring to another genus, at least at this stage of research. Therefore, the species is still described as part of the genus Elektoriskos with a question mark and can be further revised again.

\section{SYSTEMATICS INCERTAE SEDIS} G R O U P ACRITARCHA EVITT, 1963 Genus Elektoriskos Loeblich, 1970

Type species-E. aurora Loeblich, 1970.

\section{Elektoriskos? williereae (G. \& M. Deflandre, 1965)} Vanguestaine, 1979 emend. nov.

Plate I, figs. 1-13

Baltisphaeridium aff. polytrichum (Valensi): Stockmans, Williere, 1963, v. 71, p. 460, pl. 3, figs. 24, 25; text-fig. 16; Martin, 1966, p. 357, text-fig. 3.

Micrhystridium williereae G. \& M. Deflandre: Deflandre, Deflandre-Rigaud, 1965, fiche no. 2437.

Baltisphaeridium chiggerum Cramer, 1968: Cramer, 1969, pl. 70, fig. 18.

Elektoriskos pogonius Loeblich sp. nov.: Loeblich, 1970, p. 718, fig. 13A.

Comasphaeridium williereae (G. \& M. Deflandre, 1965) Cramer (New combination): Cramer, 1970 p. 121; Sheshegova, 1984, p. 31, Pl. II, figs. 11-13.

Elektoriskos williereae (G. \& M. Deflandre) Vanguestaine comb. nov.: Vanguestane, 1979, p. 247, Pl. 1, figs. 13, 14; Martin, 1989b, p. 5, Pl. 1, figs. 1-16.

Baltisphaeridium lamellum Sheshegova sp. nov.: Sheshegova, 1984, p. 31, Pl. I, figs. 11-13.

Gorgonisphaeridium sp. 1: Raevskaya, Dronov, 2014, p. 303, fig. 2F. ?Gorgonisphaeridium sp. A: Raevskaya, 2017, p. 278, figure, fig. 3.
D i a g n o s i s (emended). Vesicle apparently single-layered, spherical central body densely ornamented by distinctly differentiated flexuous simple processes of different length made of the same material as the vesicle wall. One specimen can possess two types of processes (concerning thickness), i.e., spaghetti-like and hairlike ones. Both are of similar structure having constant thickness from base to top with angular proximal contact and rounded tip which can also be either slightly inflated or club-shaped. Processes length varies from rather short to two-three times longer at the same specimen. The average process length of different specimens is also variable: from $1 / 10-1 / 15$ of the central body diameter to more or less equal to it. The longest processes may exceed the central body diameter by factor of about 1.5 , but average process length never goes beyond the diameter size. Processes are solid and do not communicate with cavity of the central body. Surface of processes and central body is psilate. Type of vesicle excystment is unknown.

Description. The vesicle apparently singlelayered, thick-walled, and weakly transparent. The central body globular, densely covered with clearly differentiated flexuous processes of various length, made of the same material as the vesicle wall. The structure of the processes is conventionally cylindrical; i.e., the thickness is practically unchanged along the entire length. The apices are simple, rounded, sometimes slightly swollen up to claviform (Plate I, figs. 5, 7). The contact of the processes with the central body is angular. The same specimen may have two types of processes of different thickness. The most abundant of them resemble long spaghetti $(0.5-0.75 \mu \mathrm{m}$ in diameter); others, present in subordinate amounts, are thin, hairlike, up to $0.25 \mu \mathrm{m}$ in diameter (Plate I, figs. 2, 4, 9,10 , and others). The process length varies both within the same specimen and in different specimens (Figs. 3a-3f); there are vesicles with different mean values of the process length from conventionally short, about $1 / 10$ of the diameter of the central body and less (Plate I, figs. 1, 2, Fig. 3a), to long, comparable with or exceeding the diameter (Plate I, figs. 9-11, Fig. 3f). All processes are solid, without an internal cavity and

Plate I. Elektoriskos? williereae (G. \& M. Deflandre) Vanguestaine, 1974 emend. nov. The scale bar size is $20 \mu \mathrm{m}$. The images of figs. 3, 6, 9, 12 with differential interference contrast (DIC). (1) Sample no. A-13-II-10, EF: R41, specimen with predominantly short processes, arrows indicate different thickness of processes with rounded apices; Moyero River, Dzheromo Formation, upper part of the Baksan Horizon; (2) Sample no. A-II-09-13, EF: S20, arrows indicate different thickness of the processes; Bolshaya Nirunda River, Dolbor Formation, Dolbor Horizon; (3) Sample no. A-13-II-10, EF: K26/1; Moyero River, Dzheromo Formation, upper part of the Baksan Horizon; (4) Sample no. A-II-09-12, EF: C28/3, arrows indicate different thickness of the processes; Bolshaya Nirunda River, Dolbor Formation, Dolbor Horizon; (5) Sample no. A-II-09-12, EF: M32/4, arrows point to clavate extensions of the apices of the processes; Bolshaya Nirunda River, Dolbor Formation, Dolbor horizon; (6) Sample no. A-13-II-10, EF: M39, Moyero River, Dzheromo Formation, upper part of the Baksan Horizon; (7) Sample no. A-I-09-11/1, EF: Q41/4, arrows indicate clavate extensions of the apices of the processes; Bolshaya Nirunda River, upper part of the Mangazei Formation, upper part of the Baksan Horizon; (8) Sample no. A-II-09-13, EF: F21; Bolshaya Nirunda River, Dolbor Formation, Dolbor Horizon; (9) Sample no. A-13-II-10, EF: N24/1.3, arrows indicate different thickness of processes; Moyero River, Dzheromo Formation, upper part of the Baksan Horizon; (10) Sample no. A-13-I-15, EF: U33/1, arrows indicate different thickness of processes; Moyerokan River, Dzheromo Formation, Dolbor Horizon; (11) Sample no. A-II-09-12, EF: Q18/2, specimen with processes exceeding the diameter of the central body; Bolshaya Nirunda River, Dolbor Formation, Dolbor Horizon; (12) Sample no. A-13-I-6, EF:M,N29/4.2; Moyerokan River, Dzheromo Formation, upper part of the Baksan Horizon. 


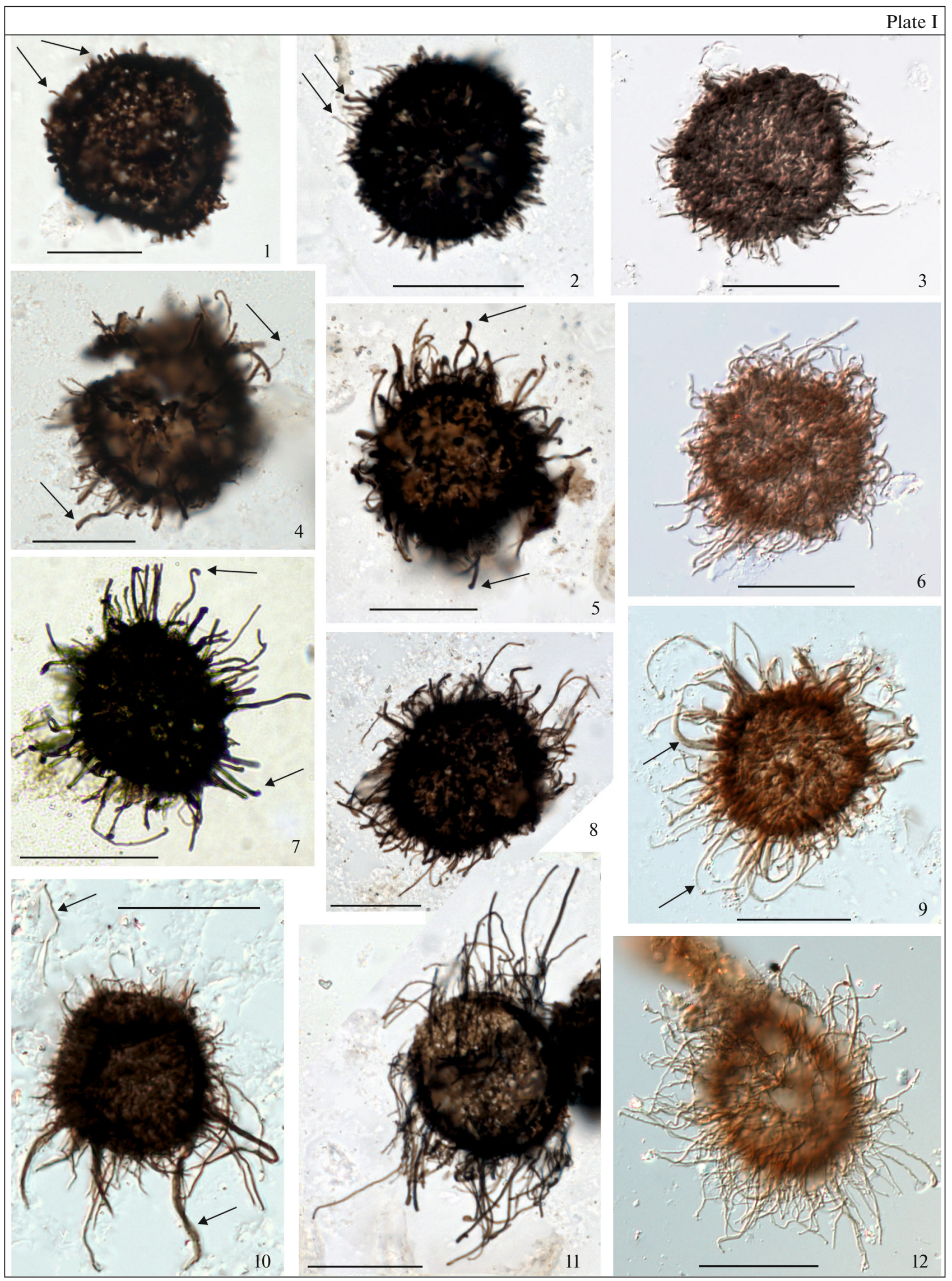




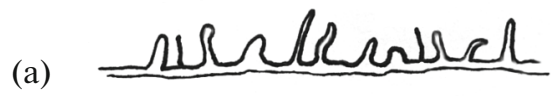

(b)

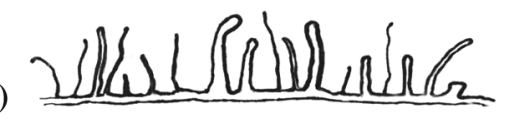

(c)

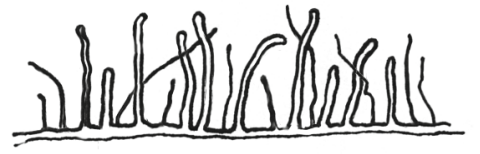

(d)
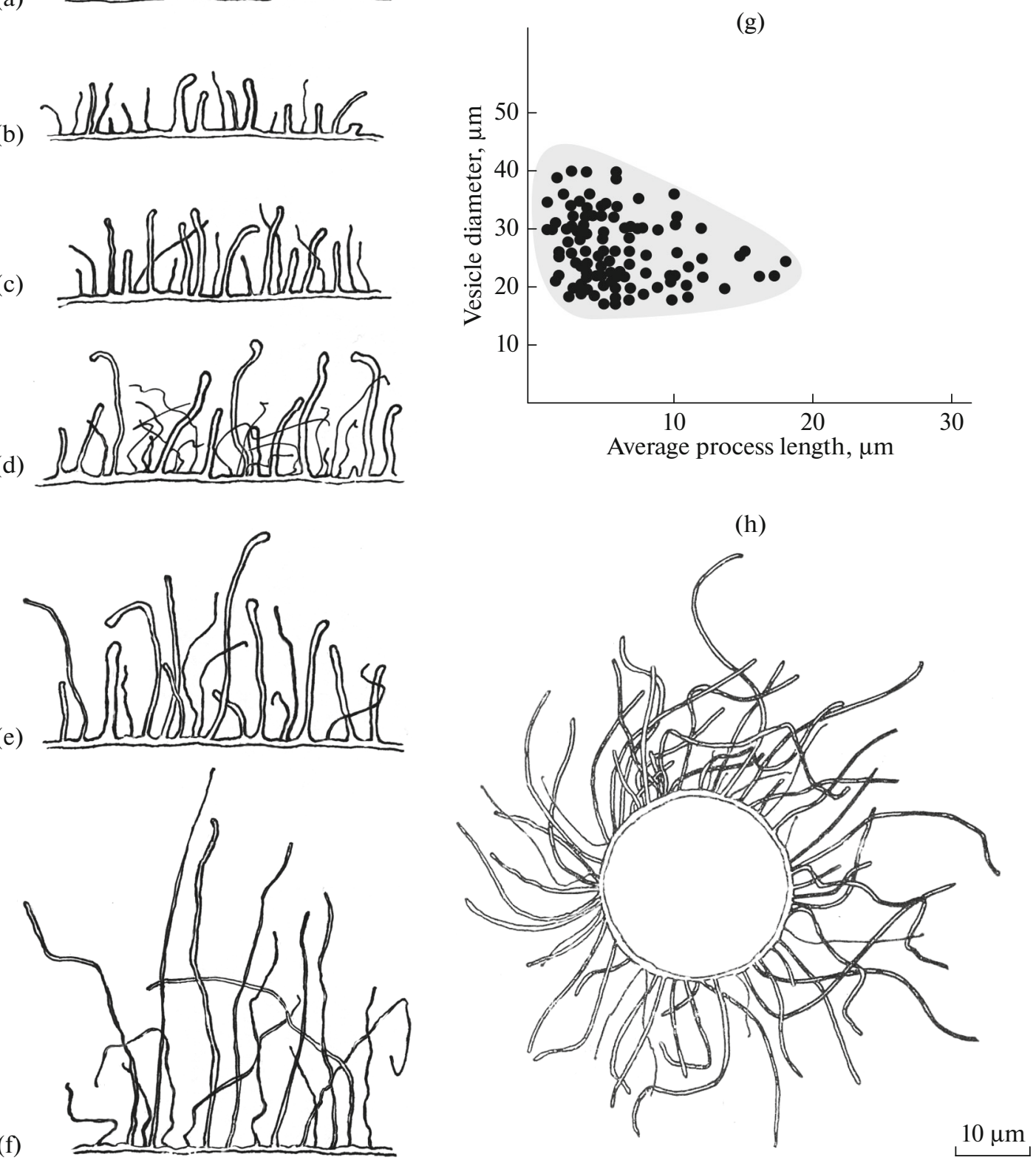

(f)

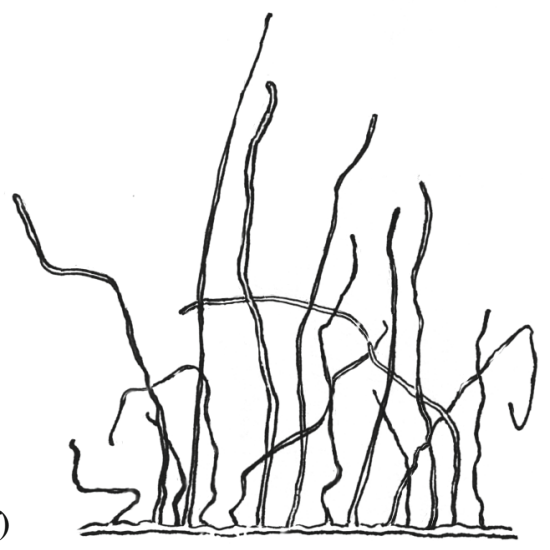

Fig. 3. Morphology of Elektoriskos? williereae (G. \& M. Deflandre) Vanguestaine, 1974 emend. nov. (a-f) Schematic structure of the processes, a continuous series of the process length and width variations, (g) the distribution of the estimated parameters (vesicle diameter, average value of the process length), (h) the vesicle structure (after Cramer, 1970, emended). The length of the scale bar is $10 \mu \mathrm{m}$.

not communicating with the vesicle cavity. The surfaces of both the processes and the vesicle are smooth. The type of vesicle opening is undefined.

S i ze $(\mu \mathrm{m})$ : diameter of the central body $18-40$ (average 29), average length of processes $2-18$, width $0.2-0.75$. Ninety-seven specimens were measured (Fig. 3g).

The variability of the taxon is mostly confined to the variability in the size of the processes. In spite of the fragility of processes and the fact that some of them are undoubtedly broken, it should be stated, however, that the processes with rounded or clavate tips are most likely whole; thus, their actual size can differ by factor of 2-3 or more in the same specimen. In addition, the population studied contains vesicles with different mean values of the process length. In some, the average size of the processes does not exceed $1 / 10-1 / 15$ of the body diameter (Plate I, figs. 1,2 ); in others, it is comparable with it, while the length of 


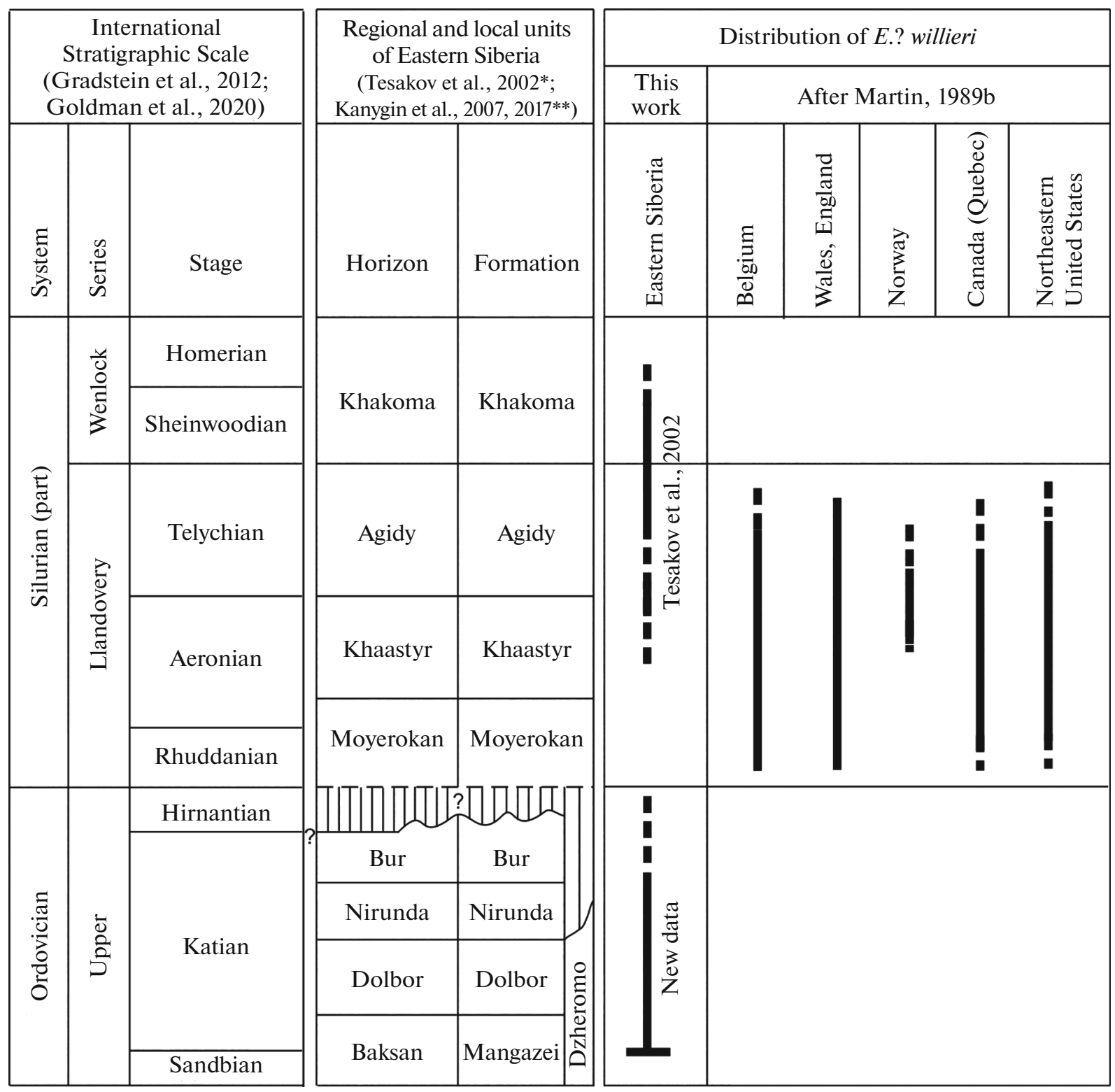

Fig. 4. Stratigraphic distribution of Elektoriskos? williereae (G. \& M. Deflandre) Vanguestaine, 1974 emend. nov. in different regions. Asterisks indicate stratigraphic links: *-Silurian, **-Ordovician.

some individual processes may exceed the diameter of the central body by factor of more than 1.5 (Plate I, figs. 9-11). It is not possible, however, to divide the population into morphologically consistent groups that could be interpreted as independent morphotypes (species/subspecies), since there are all sorts of intermediate forms that make up a continuous series (Fig. 3g). Moreover, specimens with average measured parameters prevail. The number of processes on the visible surface of different vesicles varies insignificantly and is about $80-100$, sometimes reaching 130 . The degree of vesicle ornamentation, manifested in the size (development) of processes, is most likely associated either with the maturity of the organism or with its ecological sensitivity. The varying degrees of preservation, i.e., mechanical damage to the processes was also taken into account, but considered last (see Remarks).

C o m p a r i s o n. It differs from other species of the genus in processes of different size with rounded tips.

Comparison with the species Baltisphaeridium lamellum and Comasphaeridium williereae described in the Silurian deposits of the Siberian Platform (Sheshegova, 1984) revealed practically no differences. The exclusion of these forms from the synonymics of $E$.? williereae due to the difficulties of comparison (Martin, 1989b), in our opinion, is unfounded, since the "poorly preserved" samples were complemented by 
descriptions that are almost identical to each other and do not contradict the diagnosis of E.? williereae. According to Sheshegova (1984, p. 31), Comasphaeridium williereae from the Agidy and Khakoma formations of the Upper Llandovery-Wenlok section of the Moyero River is represented by small spherical bodies covered with numerous short straight and flexuous thin processes of various lengths, which are characterized by parallel edges along their entire length and a broadly rounded apices. The accompanying taxon Baltisphaeridium lamellum, discovered by Sheshegova in the Moyero section of the Khakoma Formation and also found in the Tukal Formation of the section of the Kureyka River, is described as "a spherical body, densely covered with processes with almost parallel edges and rounded apices; some processes are more or less curved, the process lengths are different" (Sheshegova, 1984, p. 26). Both taxa are considered here as morphotypes of the same series of $E$.? williereae.

$\mathrm{R} \mathrm{e} \mathrm{m}$ a r k s. In her revision of $E$. williereae, Martin (1989b) indicated that the processes are often broken. This note, apparently, hindered further assessment of the taxon variability. At the same time, the photographs presented in her work, taken with either optical or scanning microscopes, show both actually broken processes and processes with rounded and slightly swollen apices, the latter being either long (exceeding the diameter of the central body) or short (within the size of the central body) (Martin, 1989b, p. 12, pl. 1, figs. $3,7,13)$. Also, there are two types of processes: thick spaghetti-like (the major part) and thin hairlike (sparse) (Martin, 1989b, p. 12, pl. 1, figs. 3, 12, 14). These morphological features, however, were not mentioned in Martin's extended diagnosis of the species. In addition, the photo plate illustrating the description of $E$. williereae shows a specimen with short processes, the length of which, on average, does not exceed half the vesicle diameter (Martin, 1989b, p. 12, pl. 1, fig. 1). It is hardly believable that all these processes were broken approximately along the same length. In addition, given that Martin had at her disposal a very representative collection of at least 300 specimens of E. williereae, it would be improbable that none of them was fully preserved, that is, according to diagnosis, retaining the processes 1.5 times longer than the vesicle diameter.

It is also difficult to explain the selective fragility of the processes of this particular taxon. The degree of preservation of all palynological material from the studied sections of the Bolshaya Nirunda, Moyero, and Moyerokan rivers is approximately the same. The pollen spectra of the samples also contain other acanthomorphic acritarchs with rather long processes (Raevskaya and Dronov, 2014, 2015), some of which are undoubtedly damaged. A comparison, however, leaves no doubt that the different lengths of E.? williereae processes in the material studied has a completely different (not mechanical or not only mechanical) nature.
Thus, the observations indicate that such morphological features as different lengths of flexuous processes of two types (spaghetti-like and hairlike) are considered here as stable diagnostic features of the taxon E. williereae. Its generic assignment remains open to question.

Among the acritarchs with processes devoid of an internal cavity that are closest in morphology to the genus Elektoriskos are Comasphaeridium Staplin et al., 1965, Gorogonisphaeridium Staplin et al., 1965, and Filisphaeridium Staplin et al., 1965. All these genera have similar characteristics of the vesicle structure: the spherical central body is covered with numerous processes made of the same material as the wall. Comasphaeridium bears the most densely spaced hairlike processes, which under an optical microscope sometimes look like a continuous sheet or a wide fringe framing the central body. Gorogonisphaeridium is distinguished by sparser and thicker processes with blunt apices. Filisphaeridium processes, also cylindrical in shape, are characterized by distal differentiation in the form of thickening or even branching apices. The diagnosis of Elektoriskos is defined briefly as "Circular to subcircular central body, wall apparently single-layered, psilate, chagrenate to granulate with numerous slender, flexible but solid processes which do not communicate with the interior of the central body" (Loeblich, 1970, p. 717). At the same time, the type species E. aurora bears uniform thin processes with sharp tips (Loeblich, 1970 , p. 760, figs. 12A-12D). Apparently, the morphological characteristics allows E.? williereae to be attributed to any of the above genera, under the assumption that different length and width and claviform apices of the processes do not constitute the generic character or the cause for founding a new genus. To resolve this issue, one should revise all these genera and their species composition, which is obviously beyond the scope of the present paper. Such study, however, may be implemented in the future.

L o c a ti o n. Dzheromo Formation of the Moyero and Moyerokan sections; upper part of the Mangazei Formation; Dolbor, Nirunda, and Bur formations of the Bolshaya Nirunda section; upper part of the Baksan, Dolbor, Nirunda, and Bur horizons; Katian Stage of the Upper Ordovician, Eastern Siberia.

Distribution. Eastern Siberia: Dzheromo Formation of the Moyero and Moyerokan sections; the upper part of the Mangazei Formation; Dolbor, Nirunda, and Bur formations of the Bolshaya Nirunda section; upper part of the Baksan, Dolbor, Nirunda, and Bur horizons; Katian Stage of the Upper Ordovician (this work). Khaastyr, Agidy, and Khakoma formations of the Moyero River section; upper part of Llandovery and the Wenlock of the Silurian (Sheshegova, 1984; Tesakov et al., 2002); the Tukal Formation of the Ludlow of the Kureyka River section (Sheshegova, 1984). 
Outside the Siberian Platform, the geographical distribution of $E$. williereae is rather wide: Belgium, Wales (UK), Norway, Canada (Quebec), northeastern United States, where, according to the revision by Martin (1989b), the taxon is confined to the Llandovery sediments, appearing slightly above the base of the Rhuddanian Stage and gradually disappearing at the end of the Telychian (Fig. 4). However, taking into account the new data obtained on the Siberian Platform, the first appearance of E. williereae is confined to the lower parts of the Katian Stage near the border with the Sandbian Stage (Fig. 4). The upper limit of E.? williereae was not evaluated in this work because of the lack of relevant material.

$\mathrm{M}$ a t e $\mathrm{r}$ i a 1 . There were 180 specimens of satisfactory and good preservation.

\section{DISCUSSION}

As was already mentioned in the section devoted to the stratigraphy of the Upper Ordovician of the Siberian Platform, there are still no reliable grounds for correlation of the Siberian horizons with the GSS and ISS based on direct biostratigraphic substantiation by orthogroups. The boundary between the Sandbian and Katian stages is drawn approximately in the upper part of the Baksan Horizon. Taking into account the ${ }^{206} \mathrm{~Pb} /{ }^{238} \mathrm{U}$ zircon date of $450.58 \pm 0.27 \mathrm{Ma}$ of the bentonite interlayer in the upper part of the Mangazei Formation, corresponding to the upper part of the Baksan Horizon (Huff et al., 2014), it can be assumed that the deposits stratigraphically above the dated layer are obviously related to the Katian Stage. No ash layers were found in the section of the Mangazei Formation studied in the cliffs of the Bolshaya Nirunda River. However, comparison of a series of outcrops in the middle reaches of the Podkamennaya Tunguska (Huff et al., 2014) suggests that the uppermost part of the Mangazei Formation is exposed in the section of the Bolshaya Nirunda River (Fig. 2). E.? williereae was found only in the uppermost samples of the formation, while the ten samples analyzed collected from the lower part of the section were devoid of this species. A similar situation was observed in the northeastern sections of the Tungus basin on the Moyero and Moyerokan rivers. E.? williereae was not found in the lower samples of the middle part of the Dzheromo Formation, corresponding to the lower part of the Baksan Horizon. It appears higher up the section. The exact position relative to the GSS and ISS is questionable. Thus, in this work, on the basis of the available material, it was established that the level of the first appearance of E.? williereae is confined to the boundary interval of the Sandbian and Katian stages of the Late Ordovician. New evidence may help define this level more accurately.

Despite the fact that the stratigraphic distribution of E.? williereae was significantly expanded in this study, the potential of the species under consideration for the regional stratigraphy of the Siberian Platform has increased. The first appearance of E.? williereae in the upper part of the Baksan Horizon provided a substantiation for the fact that the age of the host rocks is no older than the Sandbian-Katian boundary of the Late Ordovician. Abundant presence of E.? williereae along with representatives of the genera Gordonirundum, Nirundella, Peteinosphaeridium, and Sacculidium (Raevskaya and Dronov, 2014; Raevskaya and Servais, 2017) is a distinct palynological characteristic of the Katian Stage of the Siberian Platform.

The established relationship of some Paleozoic acritarchs with dinoflagellates (Moldowan and Talyzina, 1998; etc.) gives grounds for the similar comparison in the context of their response to the paleoecological environment. Thus, an experimental study of the response of modern dinoflagellates Lingulodinium machaerophorum to environmental changes has shown that the roughness of their sculpture, including the length of cyst processes, is closely related to changes in temperature and salinity of water (Kokinos and Anderson, 1995; Mertens et al., 2009). Similarly, manifestation of genetically inherent morphological features of acantomorphic acritarchs could have depended on paleoecological factors; also, different taxa could have reacted in different ways. The assumptions repeatedly reflected in the literature (Kroeck et al., 2020; Servais et al., 2004; etc.) about ecophenotypism of acritarchs comparable to those experimentally proven for dinoflagellates (Dale, 1996; Ellegaard, 2000; Kokinos and Anderson, 1995; Mertens et al., 2009) may be true for E.? williereae.

Morphological variations of $E$.? williereae are a stable diagnostic feature of the species, distinguishing it from other taxa with usually more sustained ornamentation. It is possible that the processes of E. ? williereae elongated chaotically under certain conditions, responding to fluctuations in external parameters, as in some modern dinoflagellates. It is still difficult to trace such patterns in fossil material. Some special lithofacies study may be able to clarify this issue in the future. However, supposed responsiveness of the species to changing environments and its high adaptability could have been a factor that allowed it, remaining almost unchanged, to overcome the global Late Ordovician cooling, which turned out to be fatal for many other organisms.

\section{CONCLUSIONS}

The study allowed the morphological structure of one of the most characteristic acritarch taxa of the Upper Ordovician of the Siberian Platform, Elektoriskos? williereae, to be clarified and supplemented. The new data expanded the range of distribution of the taxon previously considered Silurian and used as an index species for the Llandovery. According to Siberian materials, its first appearance (FAD) is confined 
to the boundary interval of the Sandbian and Katian stages of the Late Ordovician.

Morphological variations of Elektoriskos? williereae appear to have resulted from sensitivity of the species to environmental changes. However, this assumption is purely hypothetical, since the mechanism of the morphological response of acritarchs on the influence of the paleoecological environment is still poorly understood.

\section{FUNDING}

The study by Raevskaya was supported by the Russian Foundation for Basic Research, grant no. 19-05-00748 "Regional and Global Aspects of the Event of the Great Ordovician Biodiversification on the Siberian and Russian Platforms," and Dronov appreciates support from the Russian Science Foundation, grant no. 20-17-00198 "The Main Stages of the Evolution of Sedimentation, Biota, and Magnetic Field in the Ordovician of the Siberian Platform." This work is also a contribution to the International Project IGCP 653.

\section{OPEN ACCESS}

This article is licensed under a Creative Commons Attribution 4.0 International License, which permits use, sharing, adaptation, distribution and reproduction in any medium or format, as long as you give appropriate credit to the original author(s) and the source, provide a link to the Creative Commons license, and indicate if changes were made. The images or other third party material in this article are included in the article's Creative Commons license, unless indicated otherwise in a credit line to the material. If material is not included in the article's Creative Commons license and your intended use is not permitted by statutory regulation or exceeds the permitted use, you will need to obtain permission directly from the copyright holder. To view a copy of this license, visit http://creativecommons.org/licenses/by/4.0/.

\section{REFERENCES}

Bergström, S.M., Chen, Xu, Gutiérrez-Marco, J.C., and Dronov, A.V., The new chronostratigraphic classification of the Ordovician System and its relations to major series and stages and to $\delta^{13} \mathrm{C}$ chemostratigraphy, Lethaia, 2009, vol. 42, pp. 97-107.

Cramer, F.H., Possible implications for Silurian paleogeography from phytoplankton assemblages of the Rose Hill and Tuscarora formations of Pennsylvania, J. Paleontol., 1969, vol. 43, no. 2, pp. 485-490.

Cramer, F.H., Distribution of Selected Silurian Acritarchs, Madrid: Revista Espan. Micropaleontol., 1970.

Cramer, F.N. and Diez de Cramer, M., Consideraciones taxomómicas sobre las acritarcas del Silúrico Medio y Superior del Norte de España. Las acritarcas acantomorfíticas, Boletín I. G. M. España, 1968, vol. 79, pp. 541-574.

Dale, B., Dinoflagellate cyst ecology: modelling and geological applications, in Palynology: Principles and Applications, 3, Jansonius, J. and McGregor, D.C., Eds., Dallas
(TX), USA: Am. Assoc. Stratigr. Palynol. Found., 1996, pp. 1249-1275.

Deflandre, G. and Deflandre-Rigaud, M., Fichier micropaléontologique général-Série 13. Acritarches 2. Acanthomorphytae 1. Genre Micrhystridium Deflandre sens., Arch. Orig. Centre Documentacion C. N. R. S. Paris, 1965, no. 402, pp. 1-5, Fiches 2176-2521.

Dorning, K.J., Silurian acritarchs from the type Wenlok and Ludlow of Shropshire, England, Rev. Palaeobot. Palynol., 1981, no. 34(2), pp. 175-203.

Downie, C., The geological history of the microplankton, Rev. Palaeobot. Palynol., 1967, no. 1, pp. 269-281.

Downie, C., Evitt, W.R., and Sarjeant, W.A.S., Dinoflagellates, hystrichospheres and the classification of the acritarchs, Stanf. Univ. Publ. Geol. Sci., 1963, vol. 7, pp. 1-16.

Dronov, A.V., Late Ordovician cooling event: evidence from the Siberian Craton, Palaeogeogr., Palaeoclimatol., $\mathrm{Pa}$ laeoecol., 2013, vol. 389, no. 1, pp. 87-95.

Dronov, A.V., Ordovician sequence stratigraphy of the Siberian and Russian platforms, in Advances in Sequence Stratigraphy, Montenari, M., Ed., Stratigraphy \& Timescale, Spec. vol. 2, no. 2017, pp. 187-241.

Eisenack, A., Cramer, F.H., and Diez, M. del C.R., Katalog der fossilen Dinoflagellaten, Hystrichosphären und Verwandten Mikrofossilien. Band IV: Acritarcha 2, Teil. E, Stuttgart: Schweizertbart'sche Verlagsbuchhandlung, 1976.

Ellegaard, M., Variations in dinoglagellate cyst morphology under conditions of changing salinity during the last 2000 years in the Limfjord, Denmark, Rev. Palaeobot. Palynol., 2000, no. 109 , pp. $65-81$.

Evitt, W.R., A discussion and proposals concerning fossil dinoflagellates, hystrichospheres, and acritarchs, Proc. Nat. Acad. Sci. U.S.A., 1963, no. 49, pp. 298-302.

Fatka, O. and Brocke, R., Morphologic variability in Lower Palaeozoic acritarchs: Importance for acritarch systematic, Acta Mus. Natl. Pragae. Ser., B. Hist. Nat., 2008, no. 64 (2-4), pp. 97-107.

Fensome, R.A., Williams, G.L., Barss, M.S., Freeman, J.M., and Hill, J.M., Acritarchs and fossil prasinophytes: An index to genera, species and intraspecific taxa, A.A.S.P. Contrib. Ser., 1990, no. 25.

Gradstein, F.M., Ogg, J.G., Schmitz, M.D., and Ogg, G.V., The Geological Time Scale 2012, Elsevier Sci. Ltd, 2012, 2-vols.

Goldman, D., Sadler, P.M., Leslie, S.A., with contributions by Melchin, M.J., Agterberg, F.P., and Gradstein, F.M., Chapter 20. The Ordovician Period, in Geologic Time Scale 2020, Gradstein, F.M., Ogg, J.G., Schmitz, M.D., and Ogg, G.M. Eds., Elsevier, 2020, vol. 2, pp. 631-694.

Hill, P.J., Stratigraphic palynology of acritarchs from the type area of the Landovery and the Welsh Borderland, Rev. Palaeobot. Palynol., 1974, vol. 18, nos. 1/2, pp. 11-23.

Hill, P.J. and Dorning, K.J., Appendix, I. Acritarchs, in The Llandovery Series of the Type Area, Cocks, L.R.M., Woodcock, N.H., Rickards, R.B., Temple, J.T., and Lane, P.D., Eds. Bull. British Mus. (Nat. Hist.). Geol. Ser., 1984, vol. 38, no. 3, pp. 174-176.

Huff, W.D., Dronov, A.V., Sell, B., Kanygin, A.V., and Gonta, T.V., Traces of explosive volcanic eruptions in the Upper Ordovician of the Siberian Platform, Estonian J. Earth Sci., 2014, vol. 63, no. 4, pp. 244-250. 
Kanygin, A.V., Yadrenkina, A.G., Timokhin, A.V., Moskalenko, T.A., and Sychev, O.V., Stratigrafiya neftegazonosnykh basseinov Sibiri. Ordovik Sibirskoi platformy (Stratigraphy of Petroleum Basins of Siberia. The Ordovician of the Siberian Platform), Novosibirsk: Geo, 2007 [in Russian].

Kanygin, A.V., Yadrenkina, A.G., Timokhin, A.V., Moskalenko, T.A., Gonta, T.V., Stepanova, N.I., Sychev, O.V., and Maslova, O.A., The regional stratigraphic chart of the Ordovician of the Siberian Platform (new version), Geol. Mineral.-Syr'evye Resursy Sibiri, 2017, no. 5, pp. 4-57.

Kokinos, J.P. and Anderson, D.M., Morphological development of resting cysts in cultures of the marine dinoflagellate Lingulodinium polyedrum (= L. machaerophorum), Palynology, 1995, no. 19, pp. 143-166.

Kroeck, D.M., Blanchon, M., Zacai, A., Navidi-Izad, N., Benachour, H.B., Monnet, C., Raevskaya, E., Szczepanik, Z., and Servais, T., Revision of the Cambro-Ordovician acritarch genus Vulcanisphaera Deunff, 1961, Rev. Palaeobot. Palynol., 2020, vol. 279, 104212. http://

https://doi.org/10.1016/j.revpalbo.2020.104212.

Li, J., Servais, T., and Yan, K., Ordovician acritarch genus Rhopaliophora: Biostratigraphy, palaeobiogeography and palaeoecology, Rev. Palaeobot. Palynol., 2014, vol. 208, pp. 1-24.

Lister, T.R., The acritarchs and chitinozoans from the Wenlok and Ludlow Series of the Ludlow and Millichope areas, Shropshire, Palaeontograph. Soc. Monographs, 1970, no. 528, pp. $1-100$.

Loeblich, A.R., Morphology, ultrastructure and distribution of Paleozoic acritarchs, Proc. North Am. Paleontol. Convention, Pt. G. Ultra Microplankton, 1970, pp. 705-788.

Martin, F., Les Acritarches du sondage de la brasserie Lust à Kortrijk (Courtrai) (Silurien Belge), Bull. Soc. Belge Geol., Paleontol. Hydrol., 1966, vol. 74 (nos. 2, 3, 1965), pp. 354-402.

Martin, F., Silurian acritarchs, in A Global Standard for the Silurian System, Holland, C.H. and Basset, M.G., Eds., Nat. Mus. Wales. Geol. Ser. Cardiff, 1989a, vol. 9, pp. 207-215.

Martin, F., Systematic revision of Elektoriskos williereae and Dilatisphaera williereae (Acritarchs) and its bearing on Silurian (Llandoverian) stratigraphy, Bull. Inst. R. Sci. Nat. Belg., Sci. Terre, 1989b, vol. 59, pp. 5-14.

Mertens, K.N., Ribeiro, S., Bouimetarhan, I., Caner, H., Combourieu-Nebout, N., Dale, B., De Vernal, A., Ellegaard, M., Filipova, M., Godhe, A., Goubert, E., Grøsfjeld, K., Holzwarth, U., Kotthoff, U., Leroy, S.A.G., Londeix, L., Marret, F., Matsuoka, K., Mudie, P.J., Naudts, L., Peña-Manjarrez, J.L., Persson, A., Popescu, S.-M., Pospelova, V., Sangiorgi, F., van der Meer, M.T.J., Vink, A., Zonneveld, K.A.F., Vercauteren, D., Vlassenbroeck, J., and Louwye, S., Process length variations in cysts of a dinoflagellate, Lingulodinium machaerophorum, in surface sediments: investigating its potential as salinity proxy, Mar. $\mathrm{Mi}$ cropalaeontol., 2009, vol. 70, pp. 54-69.

Miller, V.A. and Eames, L.E., Palynomorphs from the Silurian Medina Group (Lower Llandovery) of the Niagara Gorge, Lewiston, N.Y., U.S.A., Palynology, 1982, vol. 6, pp. 221-254.

Moldowan, J.M. and Talyzina, N.M., Biogeochemical evidence for dinoflagellate ancestors in the Early Cambrian, Science, 1998, vol. 281, pp. 1168-1170.
Navidi-Izad, N., Hashemi, H., Régnier, S., Kroeck, D., Yan, K., and Servais, T., Revision of the Middle-Upper Ordovician acritarch genus Orthosphaeridium Eisenack 1968 nov. emend., Rev. Palaeobot. Palynol., 2020, vol. 273, pp. 104-127.

Oradovskaya, M.M., Biostratigrafiya i fauna ordovika-silura Severo-Vostoka SSSR (Ordovician and Silurian Biostratigraphy and Fauna of Northeastern USSR), Moscow: Nedra, 1988 [in Russian].

Playford, G., Ribecai, C., and Tongiorgi, M., Ordovician acritarch genera Peteinosphaeridium, Liliosphaeridium, and Cycloposphaeridium: Morphology, taxonomy, biostratigraphy, and palaeogeographic significance, Boll. Soc. $\mathrm{Pa}$ leontol. Ital., 1995, vol. 34, pp. 3-54.

Pokrovskii, B.G., Zaitsev, A.V., Dronov, A.V., Buyakaite, M.I., Timokhin, A.V., and Petrov, O.L., C, O, S, and Sr Isotope Geochemistry and Chemostratigraphy of Ordovician Sediments in the Moyero River Section, Northern Siberian Platform, Lithol. Miner. Resour., 2018, vol. 53, no. 4, pp. 283-306.

Postanovleniya Mezhvedomstvennogo stratigraficheskogo komiteta i ego postoyannykh komissii. Vyp. 41 (Decisions of Interdepartmental Stratigraphic Committee and Its Permanent Commission. Vol. 41), St. Petersburg: Vseross. NauchnoIssled. Geol. Inst., 2012, pp. 5-20.

Raevskaya, E.G., Acritarchs and biostratigraphy of Upper Cambrian-Middle Ordovician of the northwest of East European Platform, Cand. (Geol-Mineral.) Dissertation, St. Petersburg: Sankt-Peterburg. Gos. Univ., 2000.

Raevskaya, E.G., Early Paleozoic acritarchs from the East European Platform as the basis for development of competitive biostratigrafic divisions, in Stratigrafiya i ee rol'v razvitii neftegazovogo kompleksa Rossii (Stratigraphy and Its Role in Development of Oil-and-Gas Complex of Russia), St. Petersburg: Vseross. Neft. Nauchno-Issled. Geol. Inst., 2007, pp. 33-46.

Raevskaya, E.G., Development of zonal acritarch-based scales for the Ordovician of the East European Platform, in Mater. Mezhved. rabochego soveshch. "Obshchaya stratigraficheskaya shkala i metodicheskie problemy razrabotki regional'nykh stratigraficheskikh shkal Rossii", Sankt-Peterburg, 17-20oktyabrya 2016g. (Proc. Interdepart. Workshop "General Stratigraphic Scale and Methodological Problems of the Development of Regional Stratigraphic Scales of Russia". St. Petersburg, October 17-20, 2016), St. Petersburg: Vseross. Nauchno-Issled. Geol, Inst., 2016, pp. 140-141.

Raevskaya, E.G., The Upper Ordovician Palynology of the Siberian Platform: New data, in Mater. XIV Vseross. palinol. konf., posvyashch. pamyati V.P. Grichuka "Aktual'nye problemy sovremennoi palinologii” (Proc. XIV All-Russ. Palynol. Conf. Devoted to Memory of V.P. Grichuk "Actual Problems of the Modern Palynology"), Bolikhovskaya, N.S. and Klyuvitkina, T.S., Eds., Moscow: Mosk. Gos. Univ., 2017, pp. 276-279.

Raevskaya, E. and Dronov, A., New data on acritarchs from the Upper Ordovician of the Tungus basin, Siberian Platform, Estonian J. Earth Sci., 2014, vol. 63, no. 4, pp. 300-304.

Raevskaya, E. and Dronov, A., New data on the Late Ordovician acritarchs and cryptospores from the Moyero and Moyerokan River sections, northeast of the Siberian Platform, in 12th Int. Symp. on the Ordovician System. Short Papers and Abstracts, Leslie, S.A., Goldman, D., and Orndorf, R.C., Eds., Stratigraphy, 2015, vol. 12, no. 2, pp. 128-129. 
Raevskaya, E.G. and Hints, O., Acritarchs from the Middle and Upper Ordovician of Estonia and their stratigraphic implications, in Contributions of the $13^{\text {th }}$ Int. Symp. on the Ordovician System, Novosibirsk, Russia, July 19-22, 2019, Obut, O.T., Sennikov, N.V., and Kipriyanova, T.P., Eds., Novosibirsk: Publ. House SB RAS, 2019, pp. 165-168.

Raevskaya, E. and Servais, T., New acritarch taxa from the Upper Ordovician of Siberia, Palynology, 2017, vol. 41, no. 51, pp. 95-105.

Raevskaya, E.G. and Shurekova, O.V., Modern technologies and equipment for processing of carbonate-clastic rocks for palynological analysis, in Mater. XIII Ross. palinol. konf. "Problemy sovremennoi palinologii". T. 1 (Proc. XIII AllRuss. Palynol. Conf. "Problems of the Modern Palynology.” Vol. 1), Syktyvkar: Izd. Komi Nauchn. Tsentra Ural. Otd. Ross. Akad. Nauk, 2011, pp. 103-107.

Raevskaya, E.G., Dronov, A.V., Servais, T., and Wellman, C.H., Cryptospores from the Katian (Upper Ordovician) of the Tungus basin: The first evidence for early land plants from the Siberian Platform, Rev. Palaeobot. Palynol., 2016, vol. 224, pp. 4-13.

Ribecai, C. and Tongiorgi, M., The Ordovician acritarch genus Pachysphaeridium Burmann 1970: new, revised, and reassigned species, Palaeontographia Italica, 1999, vol. 86, pp. 117-153.

Ribecai, C., Raevskaya, E., and Tongiorgi, M., Sacculidium gen. nov. (Acritarcha), a new representative of the Ordovician Stelomorpha-Tranvikium plexus, Rev. Palaeobot. Palynol., 2002, vol. 121, pp. 163-203.

Sennikov, N.V., Tolmacheva, T.Yu., Obut, O.T., Izokh, N.G., and Lykova, E.V., Zonation of the Siberian Ordovician deposits based on pelagic groups of fauna, Russ. Geol. Geophys., 2015, vol. 56. no. 4, pp. 594-610.

Servais, T., Some considerations on acritarch classification, Rev. Palaeobot. Palynol., 1995, vol. 93, pp. 9-22.

Servais, T., Stricanne, L., Montenari, M., and Pross, J., Population dynamics of galeate acritarchs at the Cambrian-Ordovician transition in the Algerian Sahara, Palaeontology, 2004, vol. 47, no. 2, pp. 395-414.

Servais, T., Vecoli, M., Li, J., Molyneux, S.G., Raevskaya, E., and Rubinstein, C.V., The acritarch genus Veryhachium Deunff 1954: Taxonomic evaluation and first appearance, Palynology, 2007, vol. 31, pp. 191-203.

Servais, T., Li, J., Molyneux, S.G., and Vecoli, M., The Ordovician acritarch genus Coryphidium, Rev. Micropaleontol., 2008, vol. 51, pp. 97-120.

Sheshegova, L.I., Akritarkhi silura severa Sibirskoi platformy (The Silurian Acritarchs of the Northern Siberian Platform), Novosibirsk: Nauka, 1984 [in Russian].
Smelror, M., Early Silurian acritarchs and Prasinophycean alga from the Ringerike District, Oslo Region (Norway), Rev. Palaeobot. Palynol., 1987, vol. 52, nos. 2/3, pp. 137-159.

Staplin, F.J., Jansonius, J., and Pocock, A.J., E Evaluation of some Acritarchous Hystrichosphere Genera, N. Jb. Geol. Paläont. Abh., 1965, vol. 123, no. 2, pp. 167-201.

Stockmans, F. and Williere, Y., Les Hystrichosphères ou mieux les Acritarches du Silurien belge. Soundage de la Brasserie Lust à Courtrai (Kortrijk), Bull. Soc. Belge Geol., Paleontol. Hydrol., 1963, vol. 71, no. 3, pp. 450-487.

Tesakov, Yu.I., Simonov, O.N., Kovalevskaya, E.O., Lopushinskaya, T.V., Bazarova, L.S., Berger, A.Ya., Divina, T.A., Moskalenko, T.A., and Khromykh, V.G., Silur severo-zapada Sibirskoi platformy (The Silurian of the Northwestern Siberian Platform), Novosibirsk: Izd. Sib. Otd. Ross. Akad. Nauk RAN, Geo, 2002 [in Russian].

Tesakov, Yu.I., Kanygin, A.V., Yadrenkina, A.G., Simonov, O.N., Sychev, O.V., Abaimova, G.P., Divina, T.A., and Moskalenko, T.A., Ordovik severo-zapada Sibirskoi platformy (The Ordovician of the Northwestern Siberian Platform), Novosibirsk: Izd. Sib. Otd. Ross. Akad. Nauk, Geo, 2003 [in Russian].

Torsvik, T.N. and Cocks, L.R., New global palaeogeographical reconstructions for the Early Palaeozoic and their generation, in Early Palaeozoic Biogeography and Palaeogeography, Harper, D.A.T. and Servais, T., Eds., Geol. Soc. London. Mem., 2013, vol. 38, pp. 5-24.

Vanguestaine, M., Remaniements d'Acritarches dans le Siegenien et l'Emsien (Dévonien Inférieur) du Synclinorium de Dinant (Belgique), Ann. Soc. Geol. Belg., Bull., 1979, vol. 101, no. 1978, pp. 243-267.

Wang, W., Servais, T., Yan, K., Vecoli, M., and Li, J., The Ordovician acritarch Dactylofusa velifera Cocchio 1982: a biostratigraphical and palaeogeographical index species, Palynology, 2015, vol. 39, pp. 125-141.

Wang, W., Monnet, C., and Servais, T., Quantitative methods used for understanding the taxonomy of acritarchs: a case study of the Middle Ordovician genus Frankea Burmann 1970, Palynology, 2017, vol. 41, pp. 69-79.

Yan, K., Servais, T., and Li, J., Revision of the Ordovician acritarch genus Ampullula Righi 1991, Rev. Palaeobot. Palynol., 2010, vol. 163, pp. 11-25.

Yan, K., Li, J., Molyneux, S.G., Raevskaya, E.G., and Servais, T., A review of the Ordovician acritarch genus Barakella Cramer \& Díez 1977, Palynology, 2017, vol. 41, pp. 80-94.

Translated by M. Hannibal 